\title{
Konya Kapalı Havzası'nda Meteorolojik Kuraklık Analizi
}

\section{Meteorological Drought Analysis in Konya Closed Basin}

\author{
Faize SARIŞ ${ }^{1}$ @, Furkan GEDİK² ${ }^{2}$
}

${ }^{1}$ Dr. Öğr. Üyesi, Çanakkale Onsekiz Mart Üniversitesi, Fen ve Edebiyat Fakültesi, Coğrafya Bölümü, Çanakkle, Türkiye

${ }^{2}$ Öğretmen/Yüksek Lisans Öğrencisi, Çanakkale Onsekiz Mart Üniversitesi, Lisansüstü Eğitim Ensititüsü, Coğrafya Anabilim Dalı, Çanakkake, Türkiye

ORCID: F.S. 0000-0002-1721-4959; F.G. 0000-0001-9063-2236

\section{öz}

Bu çalışmada Konya Kapalı Havzasında meteorolojik kuraklık durumu farklı zamansal ölçeklerde, 20 ayrı yağış serisi oluşturularak Standartlaştırılmış Yağış İndisi (SPI) yöntemiyle analiz edildi. Havzada yer alan 11 meteoroloji istasyonunun 1930-2019 yılları arasında değişik uzunluklarda kaydedilmiş aylık toplam yağışverileri kullanıldı. Veri setleri kısa süreli (aylık, mevsimlik ve 6 aylık) ve uzun süreli (12, 24 ve 36 aylık) yağış serileri olarak hazırlandı ve SPI hesaplamasından sonra Gidişler Sınaması uygulanarak, kuraklık indis değerlerindeki ısrar bileşeni istatistiksel olarak belirlendi. Konya Kapalı Havzasında farklı sınıflara (hafif, orta, şiddetli ve aşırı kurak) göre kuraklığın şiddeti değerlendirildi. Orta, şiddetli ve özellikle aşırı kuraklığın belirgin olduğu dönemler Aralık, Kış, 6 aylık ve daha uzun süreli $(12,24,36$ aylık) dönemlerdir. Gidişler sınaması sonucunda, tüm istasyonların 24 ve 36 aylık serilerin SPI değerlerinin istatistiksel olarak anlamlı olduğu belirlendi. Kurak dönemler açısından istasyonlar arasında bazı farklılıklar gözlense de, genel olarak havza da kurak dönemlerin yaklaşık olarak 10'ar yıllık aralıklarla gerçekleştiği belirtilebilir. 12 Aylık dönem için Cihanbeyli, Beyşehir, Ereğli ve Niğde; 24 aylık dönemde Aksaray, Karaman, Seydişehir ve Çumra; 36 aylık dönemin indis sonuçlarına göre ise Konya, Kulu ve Karapınar en fazla kurak yıl sayısına sahiptir. Uzun süreli kuraklıklardaki bu anlamlı eğilimler Konya Kapalı Havzasında meteorolojik kuraklığın, tarımsal ve hidrolojik kuraklığa doğru yayıldığını ve buna bağlı olarak havzanın su yenilenmesi açısından kırılganlığını açık bir şekilde gösterir.

Anahtar kelimeler: Yağış, kuraklık, SPI, Konya havzası

\section{ABSTRACT}

In this study, meteorological drought condition in Konya Closed Basin was analyzed with the Standardized Precipitation Index (SPI) method by preparing 20 separate precipitation series at different temporal scales. Monthly total precipitation data of 11 meteorology stations in the basin recorded at different time spans between 1930-2019 were used. The data sets were prepared as short term (monthly, seasonal and 6 months) and long term (12, 24 and 36 months) precipitation series and the persistence component in SPI index values was statistically determined by applying the Run's Test after SPI calculation. The severity of drought was evaluated according to different classes (mild, moderate, severe and extremely arid) in Konya closed Basin. The periods when moderate, severe and particularly extreme drought is evident are December, winter, 6 months and longer periods (12, 24, 36 months). As a result of the Run's test, it was determined that the SPI values of 24 and 36 month series of all stations were statistically significant. Although some differences are observed between the stations in terms of dry years, a decadal variation for the prominent drought can be distinguished. Cihanbeyli, Beyşehir, Ereğli and Niğde for the 12-month period; Aksaray, Karaman, Seydişehir and Çumra for the 24-month period; and Konya, Kulu, Karapınar for the 36-month period have the highest number of dry years. These significant trends in prolonged droughts clearly indicate the propagation of drought severity in the Konya closed basin from meteorological to the agricultural and hydrological drought and the vulnerability of basin in terms of water renewal.

Keywords: Precipitation, drought, SPI, Konya Basin

Başvuru/Submitted: 24.02.2021 • Revizyon Talebi/Revision Requested: 26.05.2021 • Son Revizyon/Last Revision Received: 30.05 .2021 • Kabul/Accepted: 09.06.2021 • Online Yayın/Published Online: 22.06 .2021

Sorumlu yazar/Corresponding author: Faize SARIŞ / faizesaris@gmail.com

Atıf/Citation: Saris, F., \& Gedik, F. (2021). Konya Kapalı Havzası'nda meteorolojik kuraklık analizi. Cografya Dergisi, 42, 295-308.

https://doi.org/10.26650/JGEOG2021-885519 


\section{EXTENDED ABSTRACT}

\section{Introduction}

Konya Closed Basin is located in Central Anatolia and can be characterised with restricted surface water availability and predominantly groundwater use. Both domestic and agricultural water use is high in this basin and water scarcity is the major challenge to meet this demand. Previous research conducted specifically for Konya Closed Basin emphasised the drought character based on different spatiotemporal resolution. However, detailed analysis on meteorological drought is still required. The aim of this study is to analyse meteorological drought in Konya Closed Basin on the basis 20 different time series, explain temporal changes in the frequency and severity of droughts and reveal the spatial differences; thus to determine the pressure points in the sub-basin scale in terms of drought conditions.

\section{Data and Method}

Monthly total precipitation data of 11 meteorology stations in the basin recorded at different time spans between 1930-2019 were used. Precipitation data were arranged as monthly (separately each month), seasonal (Spring, Summer, Autumn, Winter), 6-month, 12 month, 24-month and 36-month (totally 20) time series. Calculations for 24 and 36 month series were made by shifting the total precipitation of two and three years consecutively. Standardized Precipitation Index (SPI) were applied to the series of each station. Periods with outstanding drought character such as having high frequency of moderate, severe and extreme droughts were selected and tested for long-term persistence with the Run's test, and the periodicity of the data was statistically revealed. The drought severity map of the basin was prepared by using the Kriging interpolation method using the index values.

\section{Results}

Moderate droughts were mainly observed in the short-term precipitation series (monthly and seasonal). The periods in which severe and extreme drought were detected were December, winter and 6-month periods. In the short-term rainfall series, the highest year rates in the extreme drought class were reached in Ereğli (13.3\%) and Karaman (10\%) in December. Aksaray, Konya, Çumra and Ereğli are prominent stations in terms of yearly rate in severe drought class. During the transition seasons moderate drought character was detected. In long-term (12, 24 and 36 month) precipitation series, the rate of severe and extreme drought years is significantly higher than shortterm series. This situation in long-term series also constitutes an indication that agricultural and hydrological drought is developing. More intense droughts were observed in prolonged precipitation series. While the rate of severe droughts is higher in Cihanbeyli, Aksaray and Beyşehir stations, Beyşehir, Ereğli, Niğde and Seydişehir stand out in terms of extreme droughts. The rate of years defined in the severe drought category has the highest annual rate in Aksaray (18.5\%) for 12-month analysis, in Konya (12.5\%) for 24-month analysis, and in Aksaray and Beyş̧ehir stations (14.3\%) for 36-month series. For extreme droughts, Niğde has the highest rate of extreme dry years $(7.3 \%)$ as a result of 12 -montha and 24-montha analyses. According to the 36-month SPI results, the station with the highest rate of extreme drought is Beyşehir (7.1\%). According to the results of the Run's test applied to the SPI index values, all stations in the 36-month drought period series and all stations except Beyşehir and Karapınar in the 24-month series have statistically significant results. These findings emphasize the seasonality pattern in the drought series. Severe and excessive drought years were observed approximately in decadal cycles over the basin.

\section{Conclusions}

In this study, the temporal variation pattern of drought in Konya Closed Basin and its propagation in time was examined statistically with SPI analyses. Low precipitation, high evaporation, excessive water withdrawal and high agricultural water consumption are the major factors that increase the impact and severity of drought. For this reason, practices that will increase water efficiency such as limiting water consumption, especially agricultural irrigation, and reuse of waste water in different sectors, should be implemented and all water users should act within the framework of common sustainability goals. Within this context, successful basin protection action plans can be produced by joint participation of public institutions, universities, private sector and civil society and prioritizing the protection and sustainability of natural resources, and solutions can be found not only for drought but also for many problems in the basin. 


\section{GÍRIŞ}

Su yeryüzünde öncelikli olarak doğal canlı yaşamının devamı için gerekli olan temel kaynaktır. Günümüz modern dünyasında, insan etkinliklerinin tamamı doğrudan ya da dolaylı olarak bir su tüketimine neden olur. Bu nedenle su kaynakları üzerinde insan baskısı her geçen gün artmaktadır. Yağışlarla yenilenebilen yüzey ve yeraltı suları üzerindeki antropojenik baskılar dünyanın hemen her bölgesinde farklı ölçekte ve şiddette su sorunlarının oluşmasına neden olur. Bu durum ise doğal ekosistem, insan sağlığı, tarım faaliyetleri ve ekonomik koşulları doğrudan etkiler. Suyla ilgili sorunlara bakıldığında su stresi, su azlığı ve su kıtlığı dikkati çeker. Belirli bir bölge / havzada erişilebilir su durumunu ifade eden bu kavramlar, suyun hidrolojik döngü içerisinde farklı rezervuarlarda depolanma süresi ve miktarı ile ilişkili olan çeşitli kuraklık süreçleri ile bağlantılıdır. Kuraklık, yaratmış olduğu sorun ve getirdiği yıkımlar sebebiyle afet olarak nitelenmekle beraber ifade edilmesi karmaşık bir olaydır. Sık görülen meteorolojik kökenli afetlerden biri olan kuraklık, yavaş gelişmesine karşın daha uzun süre ve geniş alanlarda etkili olması sebebiyle diğer afetlerden ayrılır (Keskiner, Çetin, Uçan ve Şimşek, 2016). Geniş alanlarda ve belirli bir zaman aralığında ortalama su varlığında meydana gelen önemli azalmaları ifaden eder. Kurak-yarı kurak iklim bölgelerinden nemli iklim bölgelerine kadar bütün iklim koşullarının hâkim olduğu alanlarda meydana gelebilecek bir olaydır. İklim değişiklikleriyle beraber kuraklığın etkisi ve şiddetinde artışlar meydana gelmektedir.

Literatürde yaygın olarak meteorolojik, tarımsal, hidrolojik kuraklık olmak üzere üç tip kuraklık tanımlanır (Van Loon, 2015). Kuraklığa bağlı olarak bazı ekonomik ürünlerin arz ve talebinin sağlanamaması noktasında kuraklığın sosyo-ekonomik etkilerini öne alan ve bazı kaynaklarda sosyo-ekonomik kuraklık olarak tanımlanan bir kavram da söz konusudur (Mengü Pamuk, Anaç ve Özçakal, 2011). Meteorolojik kuraklık, belli bir dönem içerisinde yeryüzüne düşen yağış miktarının ortalamanın altına inmesiyle meydana gelir. Meteorolojik kuraklık süresinin uzaması halinde toprak neminin azalması sonucunda bitkilerin yetişme devresinde fizyolojik su ihtiyaçlarını karşılayamayacak derecede su azlığı meydana gelmesi olarak tanımlanan tarımsal kuraklık oluşur. Yağışta izlenen açıklığın daha da artmasıyla beraber toprak nemi azlığından sonra, yüzey ve yeraltı su kaynakları varlığında gözlenen azalmalar hidrolojik kuraklığı ifade eder. Sosyo-ekonomik kuraklık ise yukarıdaki üç tip kuraklıkla ilişkilidir. Su kaynakları sisteminin su talebini karşılamadaki yetersizliği veya insan sağlı̆̆ına etkileridir (Van Loon, 2015). Bütün kuraklık koşulları meteorolojik kuraklıkla başlar ve gelişir.
1951-2010 yılları arasında küresel ölçekte kuraklığın sıklığı, süresi ve şiddetinin incelendiği bir çalışmada, 1951-1970 yılları arasında Kuzey Amerika ve Avustralya, 1971-1990 yılları arasında Ekvatoral bölge ve 1991-2010 yılları arasında Akdeniz havzasının kuraklıktan etkilendiği tespit edilmiştir (Spinoni, Naumann, Carrao, Barbarosa ve Vogt, 2013). Doğu Akdeniz Havzası ve Türkiye için yapılan çalışmalar değerlendirildiğinde özellikle 1970'li yıllardan sonra toplam yağış miktarlarında azalma ve kurak koşulların etkisinde artıș (Sırdaș ve Şen, 2003; Türkeş, Koç ve Sarış, 2007; Türkeş, 2012) ve hatta çölleşmeye eğilimli alanların varlığı ortaya konmıştur (Ceylan, Akgündüz, Özveren, Erkan, Çınar ve Dermirörs, 2009). Ceylan vd. (2009) çalışmasında Türkiye'de çölleşmeye meyilli alanların Konya Ovasının doğusundan Doğu Akdeniz bölümüne doğru ilerlediği ifade etmiştir.

Konya Kapalı Havzası özelinde yapılan çalışmalardan birinde Konya, Karaman, Karapınar ve Aksaray istasyonlarının kuraklık eğilimi incelenmiş ve özellikle 1970'li yılların başı ile 2000'li yılların başlarında şiddetli kuraklığın yaşandı̆̆ 1 belirlenmiştir (Türkeş, Akgündüz ve Dermirörs, 2009). Doğan (2013) tarafindan yapılan çalışmada havzada bulunan 12 istasyonun yağış verileri 6 farklı kuraklık indisiyle analiz edilmiş ve havzada tüm zamanların \%35'inde kuraklık görüldüğü vurgulanmıştır. Bir diğer çalışmada 1984-2011 yılları arasında havza genelinde ortalama sıcaklıklarda $2-3^{\circ} \mathrm{C}$ artış ve toprak nemindeki azalmaya bağlı olarak kuraklığın şiddetlendiği tespit edilmiştir (Orhan ve Ekercin, 2015). Havzanın bir kısmını içine alan Konya il sınırları dahilinde yapılan çalışmada yıllık mutlak ve minimum sıcaklıklarda artış gözlenmişken genel olarak yağış miktarlarında anlamlı bir değişkenliğe saptanmamıştır. Sadece ilkbahar mevsiminde genel olarak anlamlı bir azalma trendi tespit edilmiştir(Kılıç, 2016). Diğer çalışmada özellikle 19982015 yılları arasında uzun kurak dönemin yaşandığı ve havzanın \%81,5'inde kurak koşulların hâkim olduğu ortaya konmuştur (Meriç, 2017). Kulu, Aksaray, Karapınar ve Çumra istasyonlarında kuraklığın araştırıldığı çalışmada ortalama sıcaklıklarda $2-3^{\circ} \mathrm{C}$ artış ve ortalama yağış miktarında azalma eğilimi gözlenmiştir. Özellikle 2000'li y1llardan itibaren kuraklığın etkisini arttırdığı vurgulanmıştır (Akın 2019).

$\mathrm{Bu}$ çalışmanın amacı Türkiye'nin önemli tarımsal üretim alanlarından birisi olan Konya Kapalı Havzası'nda farklı zamansal ölçeklerdeki yağış verisine dayanarak meteorolojik kuraklık analizi yapmak; kuraklığın şiddet ve frekansındaki zamansal değişimleri açıklamak ve alansal farlılıkları ortaya koymaktır. 


\section{VERİ VE YÖNTEM}

Araştırmada Konya Kapalı Havzası içerisinde yer alan Meteoroloji Genel Müdürlüğü'ne (MGM) ait 11 adet meteoroloji gözlem istasyonunun istasyon açılış tarihinden itibaren kaydedilen günlük toplam yağış verileri kullanıldı. İstasyon seçimi yapılırken alanı temsil edecek yoğunlukta ve optimum uzunlukta süreklilik gösteren istasyonlar seçildi. İstasyonlara ait bilgiler Tablo 1'de verildi.

Çalışmada, ilk önce yağış verileri aylık, mevsimlik (İlkbahar, Yaz, Sonbahar, Kış) ve yıllık seriler halinde düzenlendi. Öncelikli olarak bu serilere kuraklık analizi uygulandı. Elde edilen sonuçlarda öne çıkan 6 aylık (Kasım-Nisan) dönem ve daha uzun sürelerdeki kuraklık durumunu tesit edebilmek için 12 aylık 24 aylık ve 36 aylık toplam yağış serileri hazırlandı. 24 ve 36 aylık serilerde iki ve üç yıllık toplam yağışlar kaydırılarak hesaplama yapıldı ve kuraklık analizi uyguland. Standartlaştırılmış Yağış İndisi (Standardized Precipitation Index, $S P I$ ) ile yapılan bu analizlerin ardından farklı zamansal ölçeklerde kuraklığın boyutları ortaya konuldu. Daha sonra orta, şiddetli ve ekstrem kuraklıkların en fazla görüldüğü 6 dönem Gidişler sınaması ile uzun dönemli ısrar bileşeni bakımından analiz edilerek, verilerdeki periyodiklik istatistiksel olarak ortaya konuldu. Son olarak elde edilen indis değerleri kullanılarak havzaya ait kuraklık şiddeti haritası Kriging enterpolasyon yöntemi uygulanarak hazırlandı. Yöntemlere ilişkin bilgiler aşağıda verildi.

\subsection{Standartlaştırılmış Yağış İndisi (Standardized Precipitation Index, SPI)}

Mckee, Doesken ve Kleist, (1993) tarafından geliştirilen Standartlaştırılmış Yağış İndisi (buradan itibaren SPI) kuraklık çalışmalarında en yaygın kullanılan indistir. Bu yöntemde uzun dönemlere ait yağış verileri kullanılır. 3, 6, 9, 12, 24 ve 36 aylık zamansal periyotlar şeklinde analizler yapılır. SPI'ın formülü aşağıdaki gibidir:

$$
S P I=\frac{X i-X o r t}{S p}
$$

Formülde $X i$ bir zamansal periyotta herhangi bir döneme ait yağış miktarını, Xort o periyotta uzun süre gözlenen yağışın ortalama değerini ve $S p$ yağış serisinin standart sapmasını ifade eder. İndis değeri negatif ise kurak, pozitif ise nemli koşulların hâkim olduğunu gösterir. Kuraklık, indis değerinin 0'ın altına indiği dönemde başlar ve 0’ın üstüne çıktığı zaman sona erer. Böylelikle kurak dönemlerin zaman içerisinde ne kadar tekrarlandığını, kuraklık şiddetini ve kuraklık eğiliminin ne yönde olduğunu yorumlama olanağı sağlar. SPI değerleri ve kuraklık sınıflandırması ilişkisi tablo 2 de verilmiştir. $\mathrm{Bu}$ çalışmada aylık (12 seri), mevsimlik (4 seri), 6 aylık (KasımNisan), 12, 24 ve 36 aylık olmak üzere toplam 20 yağış serisinden oluşan çoklu bir inceleme dönemi oluşturuldu. Her bir dönemde düşen toplam yağış miktarlarında gözlenen değişimler SPI yöntemine göre analiz edildi.

Tablo 2. SPI Kuraklık Sınıflandırması.

Table 2. SPI Drought Classification.

\begin{tabular}{cc}
\hline SPI Değeri & Kuraklık Sınıfı \\
\hline $0 \geq$ & Kuraklık Yok \\
$0 \leq-0.99$ & Hafif Kurak \\
$-1 \leq-1.49$ & Orta Kurak \\
$-1.50 \leq-1.99$ & Şiddetli Kurak \\
$-2.00 \leq$ & Aşırı Kurak \\
\hline
\end{tabular}

SPI analizinin tercih edilme nedeni ve en önemli avantajı, uzun dönemli yağış verileri kullanılarak farklı zaman ölçeklerinde (3, 6, 12 ay gibi) hesaplanabilmesi; dolayısıyla birikimli yağış açıklarının etkilerini analiz etmek için elverişli olmasıdır. Bir olasılık dağılımına uyan uzun vadeli yağış kayıtlarına dayanan SPI'da; bu dağılım daha sonra normal dağılıma dönüştürülerek sıfır ortalama ve birim standart sapma sağlanır (Van Loon, 2015). Yeterli uzunlukta yağış

Tablo 1. Araştırmada Kullanılan Meteoroloji İstasyonlarına Ait Bilgiler.

Table 1. Information on Meteorology Stations Used in the Study.

\begin{tabular}{|c|c|c|c|c|c|c|}
\hline İstasyon Adı & İstasyon No & Veri Süresi & Enlem & Boylam & Yükselti (m) & Yıllık Toplam Yağış (mm) \\
\hline Cihanbeyli & 17191 & 1959-2019 & $38^{\circ} 39^{\prime}$ & $32^{\circ} 55^{\prime}$ & 968 & 318 \\
\hline Aksaray & 17192 & 1964-2019 & $38^{\circ} 22^{\prime}$ & $33^{\circ} 59^{\prime}$ & 963 & 345 \\
\hline Beyşehir & 17242 & 1960-2019 & $37^{\circ} 40^{\prime}$ & $31^{\circ} 44^{\prime}$ & 1145 & 494 \\
\hline Konya $\mathrm{H}$. & 17244 & 1930-2019 & $37^{\circ} 59^{\prime}$ & $32^{\circ} 34^{\prime}$ & 1020 & 325 \\
\hline Karaman & 17246 & 1959-2019 & $37^{\circ} 11^{\prime}$ & $33^{\circ} 13^{\prime}$ & 1026 & 333 \\
\hline Ereğli & 17248 & 1965-2019 & $37^{\circ} 31^{\prime}$ & $34^{\circ} 02^{\prime}$ & 1047 & 307 \\
\hline Niğde & 17250 & 1935-2019 & $37^{\circ} 57^{\prime}$ & $34^{\circ} 40^{\prime}$ & 1212 & 341 \\
\hline Kulu & 17754 & 1969-2019 & $39^{\circ} 04^{\prime}$ & $33^{\circ} 03^{\prime}$ & 1012 & 387 \\
\hline Seydişehir & 17898 & 1960-2019 & $37^{\circ} 25^{\prime}$ & $31^{\circ} 50^{\prime}$ & 1134 & 767 \\
\hline Çumra & 17900 & 1972-2019 & $37^{\circ} 33^{\prime}$ & $32^{\circ} 47^{\prime}$ & 1015 & 322 \\
\hline Karapınar & 17902 & 1964-2019 & $37^{\circ} 42^{\prime}$ & $33^{\circ} 31^{\prime}$ & 998 & 292 \\
\hline
\end{tabular}


kaydı olmaması ve uygun bir olasılık dağılımı bulunamaması SPI'nın kullanımını sınırlandırmaktadır. Bu çalışmada değerlendirilen istasyonlarda veri uzunluğu 48-89 yıl arasında değişmektedir ve SPI analizi için yeterli uzunluğu sağlamaktadır.

\subsection{Gidișler Sınaması}

Gidişler sınaması (Run Test) parametrik olmayan bir yöntem olup, zaman serilerindeki 1srar bileşenini, bir başka deyişle rastgele olmama durumunu belirlemek için kullanılır. Gidiş, diğer bir ifade ile "run" terimi, belirli bir gözlem dizisinde medyan değerinin altında ya da üstünde giden ardışı gözlemlerin her birini ifade eder (Sarış, 2016; Tekkanat \& Sarış, 2015). Gözlem dizisinde gidiş sayılarının düşük olması, belirli bir yönde ısrar (persistence) gözlendiğini ve dolayısıyla veride rastgele olmama (non-randomness) durumunu ifade eder. Test istatistiği z standart normal tablosuyla karşılaştırılır. \%5 anlamlılık düzeyinde, işaretine bakılmaksızın mutlak $\mathrm{z}$ değerinin 1,96'dan büyük olması halinde rastgele olmama durumunun istatistiksel olarak anlamlılığı kabul edilir (Mendenhall ve Reinmuth, 1982).

\subsection{Kriging Enterpolasyon Yöntemi}

Kriging enterpolasyonu bilinen noktaların verilerinden yola çıkarak bilinmeyen noktaların değerini tahmin eden bir tekniktir.
Bunu yaparken hem doğrudan kullanılan değerlerden hem de istatistiksel yöntemlerden faydalanarak otokorelasyon sağlar. Kriging enterpolasyonunda bilinmeyen noktalara ait ağırlıklar hesaplanırken ağırlıkların kestirim ortalaması sıfır ve varyansı minimum olacak şekilde hesaplanır. $\mathrm{Bu}$, tahmin edilen noktasal değerlerin güven derecesini gösterir. Örnekleme yapılmamış noktanın hesaplanabilmesi için nokta çevresinde en az 6-8, en çok 16-24 arasında farklı nokta kullanılır. Yapılan tahmin iki unsur içerir: trend ve rastgele hata. Trend, düzlem yani uzaydır. Uzaysal bir enterpolasyon söz konusudur. Tahmin değeri noktaların uzaklığına ve uzaysal düzenine bağlıdır. Rastgele hata ise trend etrafında lokal düzensiz değişimdir (Yaprak ve Arslan, 2008: 38; Kol ve Küpçü, 2008: 71).

\section{ARAŞTIRMA ALANI}

Konya Kapalı Havzası 3653'-39²9' kuzey enlemleri ile $31^{\circ} 07^{\prime}-35^{\circ} 03^{\prime}$ doğu boylamları arasında bulunur ve bazı kaynaklarda Orta Anadolu havzası olarak da isimlendirilir (Şekil 1). Gerçektende, Anadolu'nun ortasında, dört bir yandan dağlar ve tepelerle çevrili, çevresine göre çukurda bulunan araştırma alanı kapalı havza özelliği gösterir. Güneyde Bolkar, Geyik ve Dedegöl Dağları; batıda Cihanbeyli Platosu; kuzey ve doğuda Ekecek Dağları, Hasan ve Melendiz Dağları ile çevrelenmiş olan havzanın orta kesiminde ise Konya Ovası, Karadağ, Karacadağ,

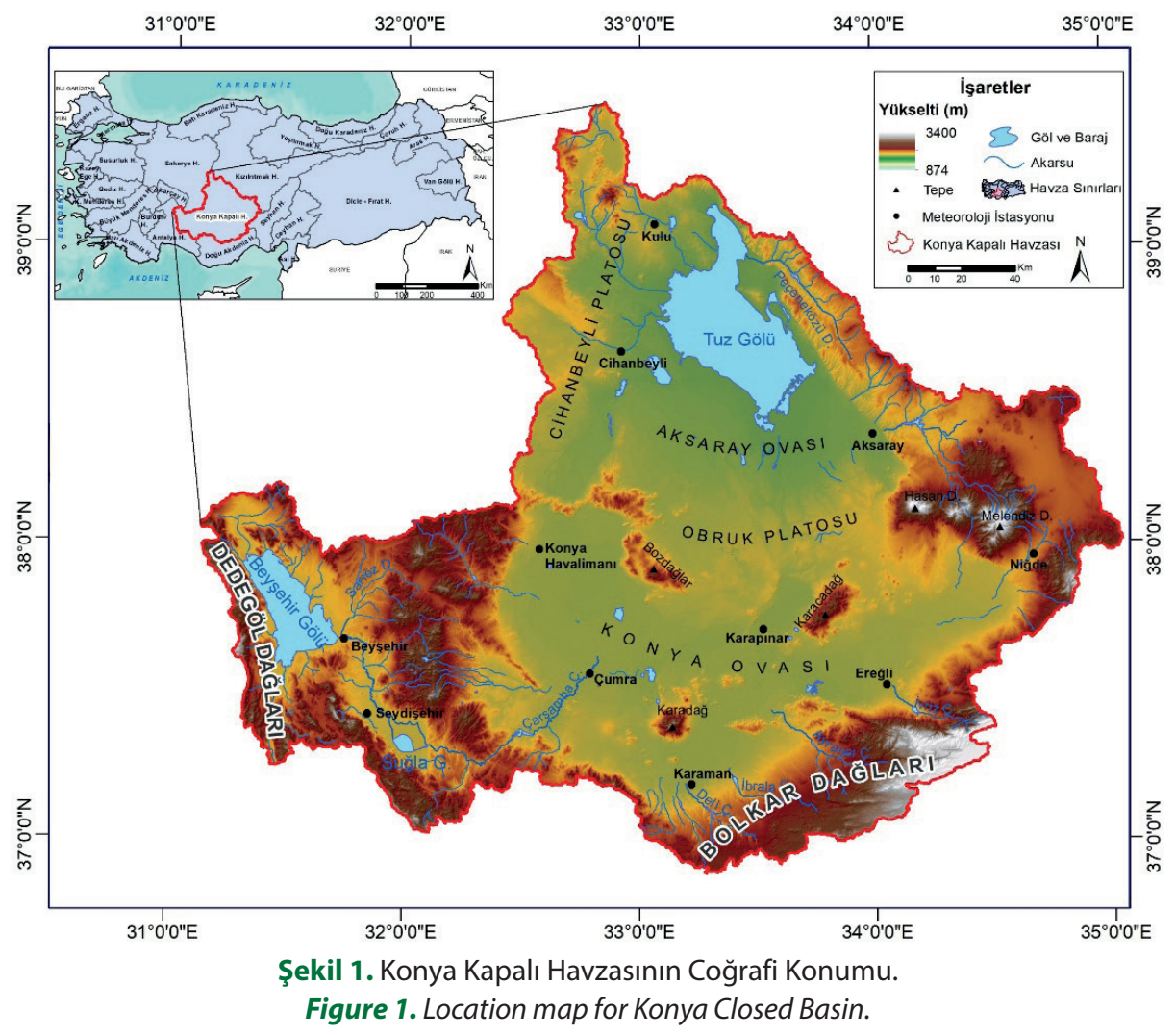


Obruk Platosu ve Aksaray Ovası yer alır. Ortalama yükseltisi 2103 metre olan havzanın en alçak ve en yüksek yerleri 874 (Tuz Gölü’nün güneyi) ve 3400 (Bolkar Dağları) metre yükseltiye sahiptir. Havzayı kuzey ve doğudan Kızılırmak, batıdan Sakarya ve Akarçay, güneybatıdan Antalya, güneyden Doğu Akdeniz ve güneydoğudan Seyhan havzaları sınırlandırır. 50 bin $29 \mathrm{~km}^{2}$ lik yüzölçümü ile Türkiye'nin en büyük kapalı havzası olan Konya Kapalı Havzası'nın topraklarının büyük kısmını Konya, Karaman, Niğde ve Aksaray illerinin bazı kısımları oluşturur. Havzada toprağ 1 bulunan diğer iller ise Nevşehir, Ankara, Isparta, Mersin ve Antalya'dır.

Havzanın yıllık ortalama yağış miktarı $391 \mathrm{~mm}$ olup yarı kurak iklim bölgesi sınıflandırmasına girer. Yağışın dağılışı havza içerisinde homojen olmayıp iklim tipleri mevkilere göre farklılıklar gösterir. Örneğin havzanın güneyinde bulunan Beyşehir ve Seydişehir İstasyonları görece olarak daha yüksek rakımda yer aldığı için yıllık toplam yağışı sırasıyla $494 \mathrm{~mm}$ ve 767 mm'dir. Bu istasyonlar kışları nispeten soğuk ve yağışlı yazları ise sıcak ve kurak iklim bölgesinde yer alır. Havzada bulunan diğer istasyonların yağış miktarları 292-387 mm arasında değişmekte olup kışları soğuk yazları sıcak ve kurak iklim tipi hakimdir (Çiftçi, Dursun, Levend ve Kunt, 2013; Çiçek ve Yılmaz, 2016; Öztürk, Çetinkaya ve Aydın, 2017; Yılmaz, 2010; Sarı ve İnan, 2011). Şekil 2'de açıkça görüleceği gibi, Seydişehir ve Beyşehir dışında diğer istasyonlarda yağış büyüklüğü ve mevsimselliği paraleldir. Bu istasyonlarda, Ocak ayından mayısa kadar olan dönemde aylık yağış ortalaması 30$45 \mathrm{~mm}$ arasında seyreder ve hem kış hem de ilkbahar yağmurlarını işaret eder. Hazirandan itibaren azalan yağış tutarları, temmuz

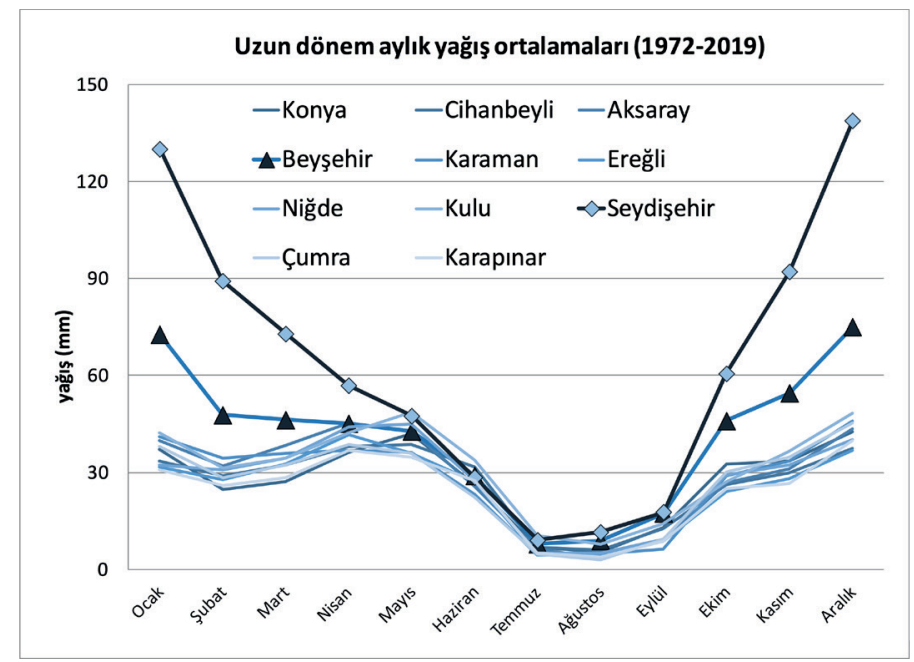

Şekil 2. Konya Kapalı Havzasındaki istasyonların uzun dönem aylık yağış ortalamaları (1972-2019).

Figure 2. Long-term monthly precipitation averages of stations in Konya Closed Basin. -eylül döneminde aylık 10 mm'nin altına iner. Ekim ile birlikte tekrar artış gözlense de bu istasyonlarda aylık toplam yağış 50 mm'yi aşmaz. Seydişehir ve Beyşehir'de kurak dönem karakteri (temmuz -eylül) diğer istasyonlar ile benzerdir ancak yağışlı dönemlerde (geç sonbahar, kış ve ilkbahar başlarına kadar uzanan bir dönem) aylık ortalam 50 mm'nin üzerinde kaydedilen yağışlar vardır. $\mathrm{Bu}$ açıdan özellikle Seydişehir kış aylarında gerçekleşen yaklaşık 390 mm'lik yağışla (toplam yağışın yarısı), yağış rejiminin mevsimselliği açısından tipik Akdeniz yağış rejimi özelliğindedir.

\section{BULGULAR}

Farklı sürelerde yağış serilerine uygulanan SPI analizinin sonuçları Tablo 3'te verildi. Kısa ve Uzun olarak iki dönem başlığı altında kuraklık analizi yapıldı. $\mathrm{Bu}$ yaklaşımın benimsenmesinin nedeni, kurak koşulların zamansal ölçekte ilerlemesine dolayısıyla kuraklığın yayılmasına ilişkin çıkarımlar ortaya koyma çabasıdır. Özellikle uzun dönemli kuraklıklar, yağış açığının zamansal ilerlemesine bağlı olarak, kuraklığın meteorolojik kuraklıktan, tarımsal ve hidrolojik kuraklığa doğru yayılmasına ve su kaynakları üzerindeki baskıya işaret eder.

Sonuçlar her bir istasyon için ayrı ayrı dönemlerde tespit edilen kurak yılların hafif kurak, orta şiddette kurak, şiddetli kurak ve aşırı kurak sınıflara yüzde olarak dağılışını gösterir. Tablo 1'de belirtildiği üzere istasyonların farklı gözlem uzunluklarına sahip olmasından dolayı, karşılaştırma yapabilmek için kurak yıl sayıları değil, her istasyonun kendi gözlem dönemine oranlanmış kurak yıl yüzdelikleri tercih edildi. Tabloda ilk dikkati çeken bulgu, Temmuz, Ağustos ve Eylül aylarında, tüm istasyonlarda gözlenen kurak yılların \%100'ü "hafif kurak" sınıfındadır. Bu aylarda mevsimsel olarak olağan bir yağış açığı olduğu için, önemli sapmalar söz konusu değildir. Bir diğer önemli bulgu da aşırı kurak yılların Aralık, Kış ve uzun dönemli serilerde (12, 24 ve 36 aylık) tespit edilmesidir. $\mathrm{Bu}$ nedenle, Konya havzasındaki istasyonlarda kuraklık büyüklüğü ve şiddeti, kuraklığın yayılışını da ortaya koyabilmek bağlamında kısa dönem kuraklık durumu ve uzun dönem kuraklık durumu olmak üzere iki alt başlıkta değerlendirildi ve hafif kuraklık dışındaki kuraklık sınıfları ele alındı.

\subsection{Kısa süreli kuraklık durumu}

Kısa süreli kuraklık durumunun tespiti için aylık, mevsimlik ve 6 aylık serilere uygulanan SPI analizi sonucunda elde edilen sonuçlar istasyon bazında değerlendirildi. 6 aylık olarak ifade edilen dönem, bir anlamda genişletilmiş kış mevsimi ya da 
Tablo 3. SPI Analizi sonuçlarına göre kurak yılların dağılışı (\%).

Table 3. Distribution of drought years according to SPI Analysis results (\%).

\section{Hafif kurak Orta Kurak Şiddetli Kurak Aşırı Kurak}

\begin{tabular}{|c|c|c|c|c|c|c|c|c|c|c|c|c|c|c|c|c|c|c|c|c|}
\hline istasyon & Ocak & Şubat & Mart & Nisan & Mayıs & Haziran & Temmuz & Ağustos & Eylül & Ekim & Kasım & Aralık & Kış & ilkbahar & Yaz & Sonbahar & 6 Aylık & 12 Aylık & 24 Aylık & 36 Aylık \\
\hline \multirow{4}{*}{ Konya } & 73.6 & 81.5 & 74.0 & 75.5 & 68.1 & 76.8 & 100.0 & 100.0 & 100.0 & 75.9 & 76.9 & 57.4 & 68.9 & 66.7 & 76.0 & 83.0 & 66.7 & 67.4 & 70.8 & 53.5 \\
\hline & 24.5 & 18.5 & 24.0 & 20.4 & 27.7 & 23.2 & 0.0 & 0.0 & 0.0 & 24.1 & 23.1 & 27.7 & 13.3 & 20.8 & 24.0 & 17.0 & 22.2 & 21.7 & 14.6 & 34.9 \\
\hline & 1.9 & 0.0 & 2.0 & 4.1 & 4.3 & 0.0 & 0.0 & 0.0 & 0.0 & 0.0 & 0.0 & 14.9 & 13.3 & 12.5 & 0.0 & 0.0 & 6.7 & 10.9 & 12.5 & 9.3 \\
\hline & 0.0 & 0.0 & 0.0 & 0.0 & 0.0 & 0.0 & & & & 0.0 & 0.0 & 0.0 & 4.4 & 0.0 & 0.0 & 0.0 & 4.4 & 0.0 & 2.1 & 2.3 \\
\hline \multirow{4}{*}{ Cihanbeyli } & 71.0 & 75.7 & 77.1 & 77.1 & 76.5 & 89.5 & 100.0 & 100.0 & 100.0 & 67.6 & 75.0 & 65.6 & 65.6 & 65.6 & 86.1 & 77.8 & 74.2 & 66.7 & 72.7 & 78.1 \\
\hline & 19.4 & 21.6 & 20.0 & 22.9 & 23.5 & 10.5 & 0.0 & 0.0 & 0.0 & 32.4 & 25.0 & 21.9 & 28.1 & 28.1 & 13.9 & 16.7 & 12.9 & 20.0 & 18.2 & 9.4 \\
\hline & 9.7 & 2.7 & 2.9 & 0.0 & 0.0 & 0.0 & 0.0 & 0.0 & 0.0 & 0.0 & 0.0 & 12.5 & 3.1 & 6.3 & 0.0 & 5.6 & 9.7 & 13.3 & 9.1 & 12.5 \\
\hline & 0.0 & 0.0 & 0.0 & 0.0 & 0.0 & 0.0 & & & & 0.0 & 0.0 & 0.0 & 3.1 & 0.0 & 0.0 & 0.0 & 3.2 & 0.0 & 0.0 & 0.0 \\
\hline \multirow{4}{*}{ Aksaray } & 71.0 & 69.0 & 67.7 & 66.7 & 77.1 & 91.9 & 100.0 & 100.0 & 100.0 & 75.8 & 64.5 & 68.8 & 70.0 & 77.4 & 82.9 & 59.3 & 77.8 & 70.4 & 59.3 & 60.7 \\
\hline & 25.8 & 17.2 & 29.0 & 23.3 & 22.9 & 8.1 & 0.0 & 0.0 & 0.0 & 24.2 & 35.5 & 18.8 & 16.7 & 12.9 & 17.1 & 29.6 & 0.0 & 7.4 & 37.0 & 25.0 \\
\hline & 3.2 & 13.8 & 3.2 & 10.0 & 0.0 & 0.0 & 0.0 & 0.0 & 0.0 & 0.0 & 0.0 & 12.5 & 13.3 & 6.5 & 0.0 & 11.1 & 18.5 & 18.5 & 0.0 & 14.3 \\
\hline & 0.0 & 0.0 & 0.0 & 0.0 & 0.0 & 0.0 & & & & 0.0 & 0.0 & 0.0 & 0.0 & 3.2 & 0.0 & 0.0 & 3.7 & 3.7 & 3.7 & 0.0 \\
\hline \multirow{4}{*}{ Beyşehir } & 77.8 & 82.9 & 75.8 & 77.1 & 81.8 & 85.7 & 100.0 & 100.0 & 100.0 & 69.7 & 69.7 & 77.1 & 65.6 & 67.7 & 81.1 & 81.6 & 70.0 & 62.1 & 68.0 & 71.4 \\
\hline & 22.2 & 14.3 & 18.2 & 22.9 & 9.1 & 14.3 & 0.0 & 0.0 & 0.0 & 30.3 & 30.3 & 22.9 & 31.3 & 22.6 & 18.9 & 15.8 & 16.7 & 24.1 & 16.0 & 7.1 \\
\hline & 0.0 & 2.9 & 6.1 & 0.0 & 9.1 & 0.0 & 0.0 & 0.0 & 0.0 & 0.0 & 0.0 & 0.0 & 3.1 & 9.7 & 0.0 & 2.6 & 13.3 & 10.3 & 12.0 & 14.3 \\
\hline & 0.0 & 0.0 & 0.0 & 0.0 & 0.0 & 0.0 & & & & 0.0 & 0.0 & 0.0 & 0.0 & 0.0 & 0.0 & 0.0 & 0.0 & 3.4 & 4.0 & 7.1 \\
\hline \multirow{4}{*}{ Karaman } & 80.6 & 73.0 & 85.3 & 89.5 & 68.6 & 73.0 & 100.0 & 100.0 & 100.0 & 71.1 & 62.9 & 59.4 & 61.3 & 58.1 & 86.8 & 65.6 & 79.4 & 75.8 & 75.0 & 81.8 \\
\hline & 13.9 & 18.9 & 8.8 & 10.5 & 28.6 & 27.0 & 0.0 & 0.0 & 0.0 & 28.9 & 37.1 & 25.0 & 25.8 & 41.9 & 13.2 & 28.1 & 8.8 & 18.2 & 15.6 & 12.1 \\
\hline & 5.6 & 8.1 & 5.9 & 0.0 & 2.9 & 0.0 & 0.0 & 0.0 & 0.0 & 0.0 & 0.0 & 15.6 & 12.9 & 0.0 & 0.0 & 3.1 & 8.8 & 6.1 & 9.4 & 6.1 \\
\hline & 0.0 & 0.0 & 0.0 & 0.0 & 0.0 & 0.0 & & & & 0.0 & 0.0 & 0.0 & 0.0 & 0.0 & 0.0 & 3.1 & 2.9 & 0.0 & 0.0 & 0.0 \\
\hline \multirow{4}{*}{ Ereğli } & 69.0 & 77.4 & 78.8 & 71.0 & 71.0 & 77.1 & 100.0 & 100.0 & 100.0 & 70.0 & 58.6 & 50.0 & 74.2 & 75.8 & 82.4 & 72.7 & 75.9 & 69.0 & 75.0 & 69.2 \\
\hline & 20.7 & 16.1 & 21.2 & 29.0 & 29.0 & 22.9 & 0.0 & 0.0 & 0.0 & 30.0 & 31.0 & 23.3 & 19.4 & 18.2 & 17.6 & 24.2 & 6.9 & 17.2 & 17.9 & 19.2 \\
\hline & 6.9 & 6.5 & 0.0 & 0.0 & 0.0 & 0.0 & 0.0 & 0.0 & 0.0 & 0.0 & 10.3 & 13.3 & 3.2 & 6.1 & 0.0 & 3.0 & 13.8 & 6.9 & 0.0 & 7.7 \\
\hline & 3.4 & 0.0 & 0.0 & 0.0 & 0.0 & 0.0 & & & & 0.0 & 0.0 & 13.3 & 3.2 & 0.0 & 0.0 & 0.0 & 3.4 & 6.9 & 7.1 & 3.8 \\
\hline \multirow{4}{*}{ Niğde } & 78.4 & 69.6 & 68.1 & 66.7 & 68.9 & 72.0 & 100.0 & 100.0 & 100.0 & 74.0 & 61.4 & 73.1 & 82.4 & 72.7 & 68.9 & 72.1 & 61.5 & 63.4 & 70.7 & 69.0 \\
\hline & 17.6 & 28.3 & 29.8 & 27.1 & 26.7 & 28.0 & 0.0 & 0.0 & 0.0 & 26.0 & 38.6 & 21.2 & 9.8 & 15.9 & 28.9 & 18.6 & 15.4 & 22.0 & 17.1 & 21.4 \\
\hline & 3.9 & 2.2 & 2.1 & 6.3 & 4.4 & 0.0 & 0.0 & 0.0 & 0.0 & 0.0 & 0.0 & 5.8 & 3.9 & 4.5 & 2.2 & 9.3 & 20.5 & 7.3 & 4.9 & 4.8 \\
\hline & 0.0 & 0.0 & 0.0 & 0.0 & 0.0 & 0.0 & & & & 0.0 & 0.0 & 0.0 & 3.9 & 6.8 & 0.0 & 0.0 & 2.6 & 7.3 & 7.3 & 4.8 \\
\hline \multirow{4}{*}{ Kulu } & 80.0 & 89.7 & 74.1 & 70.4 & 72.4 & 72.4 & 100.0 & 100.0 & 100.0 & 87.9 & 71.0 & 65.4 & 82.1 & 54.2 & 83.9 & 80.0 & 81.5 & 76.0 & 80.8 & 69.2 \\
\hline & 16.7 & 10.3 & 22.2 & 29.6 & 27.6 & 27.6 & 0.0 & 0.0 & 0.0 & 12.1 & 29.0 & 19.2 & 10.7 & 33.3 & 16.1 & 16.7 & 3.7 & 16.0 & 11.5 & 23.1 \\
\hline & 3.3 & 0.0 & 3.7 & 0.0 & 0.0 & 0.0 & 0.0 & 0.0 & 0.0 & 0.0 & 0.0 & 15.4 & 7.1 & 12.5 & 0.0 & 3.3 & 14.8 & 8.0 & 7.7 & 3.8 \\
\hline & 0.0 & 0.0 & 0.0 & 0.0 & 0.0 & 0.0 & & & & 0.0 & 0.0 & 0.0 & 0.0 & 0.0 & 0.0 & 0.0 & 0.0 & 0.0 & 0.0 & 3.8 \\
\hline \multirow{4}{*}{ Seydişehir } & 71.9 & 80.6 & 69.7 & 76.5 & 75.8 & 63.0 & 100.0 & 100.0 & 100.0 & 81.1 & 77.1 & 75.8 & 65.6 & 67.6 & 76.5 & 67.7 & 75.0 & 75.0 & 69.7 & 77.4 \\
\hline & 28.1 & 16.7 & 24.2 & 20.6 & 18.2 & 22.2 & 0.0 & 0.0 & 0.0 & 18.9 & 22.9 & 12.1 & 31.3 & 26.5 & 23.5 & 32.3 & 12.5 & 15.6 & 21.2 & 9.7 \\
\hline & 0.0 & 2.8 & 6.1 & 2.9 & 6.1 & 14.8 & 0.0 & 0.0 & 0.0 & 0.0 & 0.0 & 12.1 & 3.1 & 5.9 & 0.0 & 0.0 & 12.5 & 9.4 & 6.1 & 6.5 \\
\hline & 0.0 & 0.0 & 0.0 & 0.0 & 0.0 & 0.0 & & & & 0.0 & 0.0 & 0.0 & 0.0 & 0.0 & 0.0 & 0.0 & 0.0 & 0.0 & 3.0 & 6.5 \\
\hline \multirow{4}{*}{ Çumra } & 82.1 & 80.8 & 75.0 & 79.3 & 87.1 & 85.2 & 100.0 & 100.0 & 100.0 & 74.1 & 71.4 & 52.0 & 73.1 & 67.9 & 74.1 & 70.4 & 76.0 & 69.2 & 65.4 & 74.1 \\
\hline & 10.7 & 11.5 & 20.8 & 20.7 & 12.9 & 14.8 & 0.0 & 0.0 & 0.0 & 25.9 & 28.6 & 20.0 & 15.4 & 25.0 & 25.9 & 22.2 & 12.0 & 23.1 & 30.8 & 18.5 \\
\hline & 7.1 & 7.7 & 4.2 & 0.0 & 0.0 & 0.0 & 0.0 & 0.0 & 0.0 & 0.0 & 0.0 & 24.0 & 11.5 & 7.1 & 0.0 & 7.4 & 8.0 & 7.7 & 3.8 & 7.4 \\
\hline & 0.0 & 0.0 & 0.0 & 0.0 & 0.0 & 0.0 & & & & 0.0 & 0.0 & 4.0 & 0.0 & 0.0 & 0.0 & 0.0 & 4.0 & 0.0 & 0.0 & 0.0 \\
\hline \multirow{4}{*}{ Karapınar } & 84.4 & 80.0 & 70.0 & 74.2 & 88.6 & 58.1 & 100.0 & 100.0 & 100.0 & 69.7 & 60.7 & 43.3 & 75.8 & 75.0 & 66.7 & 75.8 & 67.9 & 68.8 & 74.2 & 65.4 \\
\hline & 12.5 & 13.3 & 23.3 & 22.6 & 11.4 & 41.9 & 0.0 & 0.0 & 0.0 & 30.3 & 39.3 & 33.3 & 18.2 & 21.9 & 33.3 & 15.2 & 14.3 & 31.3 & 16.1 & 26.9 \\
\hline & 3.1 & 6.7 & 6.7 & 3.2 & 0.0 & 0.0 & 0.0 & 0.0 & 0.0 & 0.0 & 0.0 & 13.3 & 6.1 & 3.1 & 0.0 & 9.1 & 14.3 & 0.0 & 9.7 & 7.7 \\
\hline & 0.0 & 0.0 & 0.0 & 0.0 & 0.0 & 0.0 & & & & 0.0 & 0.0 & 10.0 & 0.0 & 0.0 & 0.0 & 0.0 & 3.6 & 0.0 & 0.0 & 0.0 \\
\hline
\end{tabular}

yağışlı dönemi kapsar ve zaman aralığı Kasım ayı başından Nisan ayı sonuna kadardır. Aşağıdaki açıklamalarda oran olarak ifade edilen ise yukarıda da belirtildiği gibi ilgili kuraklık sınıfındaki kurak yıl sayısının toplam kurak yıllara oranıdır. Analiz sonuçları Tablo 3'ye dayanarak istasyon bazında değerlendirildi:

- Konya istasyonunda orta kuraklık sınıfinın oranı, toplam kuraklıkların ortalama olarak \%22'sini oluşturdu ve ay bazında en yüksek oran \%27.7 ile Aralık ve Mayıs’ta gözlendi. Şiddetli kurak yılların oranının, toplam kurak yılların \%10'unu aştığı dönemler Aralık ayı ile Kış ve İlkbahar mevsimleridir. Aşırı kuraklık \%4.4 oranıyla Kış ve 6 aylik dönemde tespit edildi.
- Cihanbeyli'de orta kuraklık sınıfının kısa dönem ortalama oran $\% 21.2$, en fazla \%32.4 ile Ekim ayında belirlendi. Şiddetli kuraklığın \%10'u aştığg dönem Aralık ayı ve aşırı kuraklık durumu da sirasiyla \%3.1ve \%3.2 oranlarıyla Kış ve 6 aylık dönemde tespit edildi.

- Aksaray istasyonunda orta kuraklık sinıfinın oranı, toplam kuraklıkların ortalama olarak \%20.1'ini oluşturdu ve ay bazında \%35.5 ile en fazla Kasım ayında gözlendi. Şiddetli kurak yılların oranının, toplam kurak yılların \%10'unu aştığı dönemler Aksaray'da diğer istasyonlardan fazladır. Şubat, Aralık, Kış ve Sonbahar ve 6 aylık dönemde şiddetli kuraklık oranları \%11-18 arasında değişir. Aşırı kuraklık \%3.7 ile 6 aylık ve \%3.2 ile ilkbaharda tespit edildi. 
- Beyşehir'de orta kuraklık sınıfının kısa dönem ortalama oranı $\% 20.7$, en fazla $\% 31.3$ ile kış mevsiminde belirlendi. Şiddetli kuraklığın \%10'u aştı̆̆ dönem yalnızca 6 aylık (\%13.3) dönemdir. Beyşehir'de aşırı kuraklık durumu tespit edilmedi. Diğer istasyonlara göre kısa süreli kuraklık şiddetinin daha zayıf olduğu bir istasyondur.

- Karaman istasyonunda orta kuraklık sinıfinın oranı, toplam kuraklıkların ortalama olarak \%22.6'sını kapsar ve \%41.9 ile ilkbaharda en yüksektir. Şiddetli kurak yılların oranının, toplam kurak yılların \%10'unu aştığı dönemler Aralık ayı ile kış mevsimidir. Aşırı kuraklık $\% 3.1$ ve $\% 2.9$ oranlariyla sirasiyla sonbahar ve 6 aylik dönemde gözlendi.

- Ereğli'de orta kuraklık sınıfının kısa dönem ortalama oran1 \%22.1'dir, \%31 ile Kasım ayında en yüksek oranda belirlendi. Şiddetli kuraklığın \%10'u aştığı dönemlere bakıldığında, Kasım, Aralık ve 6 aylık dönem öne çıkar. Aşırı kuraklık durumu \%13.3 oranıla Aralık ve \%3.2 ile kış ve \%3.4 ile 6 aylık dönemde tespit edildi. Aralık ayındaki bu yüksek oran, aylık analizler açısından değerlendirildiğinde en yüksek orandır.

- Niğde istasyonunda orta kuraklık sinıfının oranı, toplam kuraklıkların ortalama olarak \%23.7'sini oluşturdu ve ay bazında \%38.6 ile en fazla Kasım'da gözlendi. Şiddetli kurak yılların oranının, toplam kurak yılların \%10'unu aştığ kuraklık ise $\% 6.8, \% 3.9$ ve $\% 2.6$ oranlarıyla sirasıyla ilkbahar, kış ve 6 aylık dönemde tespit edildi.

- Kulu'da orta kuraklık sınıfının kısa dönem ortalama oranı \%19.6'dır, en fazla \%33.3 ile ilkbaharda belirlendi. Şiddetli kuraklığın \%10’u aştı̆̆ dönemler Aralık, ilkbahar ve 6 aylık dönemdir. Kısa süreli zaman serilerinde bu istasyon için aşırı kuraklık durumu tespit edilmedi.

- Seydişehir'e bakıldığında orta kuraklık sınıfının kısa dönem ortalama oranının \%22.1 olduğu ve en fazla \%31.3 ile kış mevsiminde öne çıktığı gözlenir. Şiddetli kuraklı̆̆ın \%10’u aştığı dönemler Haziran, Aralık, ve 6 aylık dönemdir. Özellikle Haziran ayındaki sonuç dikkat çekicidir. Kısa süreli zaman serilerinde bu istasyon için, Beyşehir ve Kulu'da olduğu gibi aşırı kuraklık durumu belirlenmedi.

- Çumra istasyonunda orta kuraklık sınıfının oranı, toplam kuraklıkların ortalama olarak \%19'unu kapsar ve \%28.6 ile Kasım ayında en yüksektir. Şiddetli kurak yılların oranının, toplam kurak yılların \%10'unu aştığı dönemler Aralık ayı (\%24) ve kış mevsimidir. Aralık ayı için bu oran tüm istasyonlar arasındaki en yüksek orandır. Aşırı kuraklık \%4 ile Aralık ve kış mevsiminde gözlendi.
- Karapınar'da orta kuraklık sınıfının kısa dönem ortalama oranı \%23.6'dir, \%41.9 ile Haziran ayında en yüksek oranda belirlendi. Benzer bir oran Karaman ilkbahar orta kuraklık sınıfı için de tespit edildi. Bu iki değer tüm analizler içinde orta şiddetli kuraklık için belirlenmiş en yüksek istasyon oranlarıdır. Şiddetli kuraklı̆̆ın \%10’u aştığı dönemlere bakıldığında Aralık ve 6 aylık dönem öne çıkar. Aşırı kuraklık durumu \%10 oranıyla Aralık ayında en yüksektir ve bu kuraklık sınıfında Ereğli’den sonraki aylık analizler açısından değerlendirildiğinde en yüksek ikinci orandır.

\subsection{Uzun süreli kuraklık durumu}

Uzun süreli (12, 24 ve 36 aylık) analizleri sonucunda, orta, şiddetli ve aşırı kuraklık sınıflarındaki kurak yıllar oranı ortalaması Konya, Aksaray, Çumra ve Karapınar da kısa süreli kuraklık sınıfı ortalamalarından yüksektir. Diğer istasyonlarda ise, uzun süreli kuraklıklar içerisinde orta kuraklık sınıfına giren yılların oranı, kısa süreli kuraklıklardan düşüktür ancak şiddetli ve aşırı kurak yılların oranı yüksektir. Bu durum uzun süreli kuraklıkların daha şiddetli olduğunun, dolayısıyla yerel fiziksel şartlara bağlı olarak değişkenlik göstermekle birlikte toprak nem açığı sonucunda ortaya çıkan tarımsal kuraklığın ve yüzey/ yeraltı su açığı olarak ifade edilen hidrolojik kuraklık için bir gösterge olarak değerlendirilebilir. Özellikle Cihanbeyli, Aksaray ve Beyşehir istasyonlarında şiddetli kuraklıkların oranı daha yüksekken, aşırı kuraklıklar açısından ise Beyşehir, Ereğli, Niğde ve Seydişehir dikkati çeker.

Tablo 4. Orta, şiddetli, aşırı kurak yılların toplam kuraklık içindeki oranı (\%).

Table 4. The ratio of moderate, severe and extremely dry years in total drought (\%).

\begin{tabular}{lccc}
\hline İstasyonlar & 12 Aylık & 24 Aylık & 36 Aylık \\
\hline Konya & 32.6 & 29.2 & $\mathbf{4 6 . 5}$ \\
Cihanbeyli & $\mathbf{3 3 . 3}$ & 27.3 & 21.9 \\
Aksaray & 29.6 & $\mathbf{4 0 . 7}$ & 39.3 \\
Beyşehir & $\mathbf{3 7 . 9}$ & 32.0 & 28.6 \\
Karaman & 24.2 & $\mathbf{2 5 . 0}$ & 18.2 \\
Ereğli & $\mathbf{3 1 . 0}$ & 25.0 & 30.8 \\
Niğde & $\mathbf{3 6 . 6}$ & 29.3 & 31.0 \\
Kulu & 24.0 & 19.2 & $\mathbf{3 0 . 8}$ \\
Seydişehir & 25.0 & $\mathbf{3 0 . 3}$ & 22.6 \\
Çumra & 30.8 & $\mathbf{3 4 . 6}$ & 25.9 \\
Karapınar & 31.3 & 25.8 & $\mathbf{3 4 . 6}$ \\
\hline
\end{tabular}

Tablo 4'ten yola çıkarak her bir uzun süreli kuraklık için ayrı değerlendirmeler yapıldı. 12 Aylık dönem için Cihanbeyli, Beyşehir, Ereğli ve Niğde istasyonları öne çıkar. Bu istasyonların uzun dönemli analizlerinde, en yüksek kurak yıl sayısına 12 aylık dönemde ulaşıldı. \%37.9 ile Beyşehir tüm istasyonlar 
içinde en yüksek orana sahiptir. 24 aylık döneme ilişkin analiz sonuçlarına göre Aksaray, Karaman, Seydişehir ve Çumra'da en yüksek kurak yıl oranına bu periyotta ulaşıldı. Bu dönemde \%40.7'lik oran ile Aksaray dikkat çeker. 36 aylık dönemin indis sonuçlarında da; Konya, Kulu ve Karapınar'ın en fazla kurak yıl sayısı ile tanımlandığı ifade edilebilir. $\mathrm{Bu}$ dönem için tüm istasyonlar içinde en fazla kurak yıl sayısına sahip istasyon Konya'dır (Tablo 4).

12, 24, 36 aylık uzun süreli SPI analizi sonucunda, farklı kuraklık sınıflarında öne çıkan istasyonlar Tablo 3'den yararlanarak değerlendirildi. Havza geneli ortalamalarda, orta kuraklık sınıfındaki yılların oranı \%19.4, şiddetli kuraklık \%8.1 ve aşırı kuraklık ise \%2.3 olarak hesaplandı. Orta kuraklık kategorisinde tanımlanan yılların oranı, 12 aylık analizlerde Karapınar'da (\%31.3) en yüksektir. Çumra ve Beyşehir de 12 aylık kuraklık değerlendirmelerinde, orta kuraklık ile tanımlanan yıl sayısı oranı yüksektir. Orta kuraklığa sahip yılların oranı 24 aylık analizlerde \%37 ile Aksaray ve \%30.8 ile Çumra istasyonlarında öne çıkar. 36 aylık SPI sonuçlarına göre ise Konya \%34.9 ile en yüksek yıl oranına sahipken, Aksaray (\%25) ve Karapınar'da (\%26.9) dikkati çeker.

Şiddetli kuraklık kategorisinde tanımlanan yılların oranı, 12 aylık analizlerde Aksaray'da (\%18.5) en yüksektir. Konya, Cihanbeylive Beyşehirde 12 aylık kuraklık değerlendirmelerinde, orta kuraklık ile tanımlanan yıl sayısı oranı olarak \%10'un üstendir. Şiddetli kurak olarak tanımlanmış yılların oranı 24 aylık analizlerde \%12.5 ile Konya ve \%12 Beyşehir öne çıar. 36 aylık veri setinin indis sonuçlarına göre ise Aksaray ve Beyşehir istasyonları \%14.3 oranı ile, Cihanbeyli de \%12.5 ile en yüksek y1l oranına sahiptir.

12, 24 ve 36 aylık da dahil olmak üzere tüm uzun süreli analizlerde Cihanbeyli, Karaman, Çumra ve Karapınar'da aşırı kurak olarak tanımlanmış yıl bulunmaz. Diğer istasyonlar incelendiğinde, Ereğli ve Niğde'de 12 aylık analizler sonucunda aşırı kurak yılların oranı sırasıyla \%6.9 ve \%7.3’tür. Aynı istasyonlar 24 aylık kuraklıkta da en yüksek yıl sayısı oranı ile dikkat çeker. 36 aylık SPI sonuçlarına göre ise havzada en yüksek yağış değerlerine sahip olan iki istasyon Beyşehir (\%7.1) ve Seydişehir (\%6.5) en yüksek yıl sayısı oranlarıyla öne çıkar.

Farklı sürelerde kurak yılların oranını değerlendirerek kuraklığın Konya Kapalı Havzasında farklı şiddet sınıflarına göre büyüklüğü değerlendirildi. Kuraklığın belirgin olduğu dönemler Aralık, Kış, 6 aylık ve daha uzun süreli (12, 24, 36 aylık) dönemlerdir. Kuraklığın genel olarak süresinin uzamasıyla şiddetinin arttığ 1 göze çarpar. Bu nedenle bir sonraki bölümde ele alınan kuraklığın dönemselliği konusunda uzun süreli kuraklıklar analiz edildi.

\subsection{Kuraklığın dönemselliği}

Kurak yılların zamansal değişkenliğini analiz etmek için gidişler sınaması uygulanarak, SPI değerlerinde israr olup olmadığına bakıldı. Böylelikle özelikle uzun süreli kuraklık analizi sonuçlarını gösteren grafiklerde gözlenen dönemselliğin istatistiksel olarak anlamlılığı test edildi. Orta, şiddetli ve ekstrem kuraklıkların en fazla görüldüğü 6 dönem, Gidişler sınaması ile uzun dönemli ısrar bileşeni bakımından analiz edildi. Tablo 5'te 1973-2019 ortak dönemi için uygulanan gidişler sınaması sonucunda elde edilen test istatistikleri verildi. Burada bir not düşmek gerekir; gidişler sınaması her bir istasyon için kendi gözlem dönemi için de uygulandı. Elde edilen sonuçlar açısından farklılık olmadığ 1 için, karşılaştırmada kolaylık sağlaması açısından 47 yıllık ortak döneme ait analiz sonuçları verildi.

SPI değerlerine uygulanan Gidişler sınaması sonuçlarına göre, 36 aylık serilerinde tüm istasyonlar, 24 aylık serilerde ise Beyşehir ve Karapınar hariç bütün istasyonlar istatistiksel olarak anlamlı sonuçlara sahiptir (Tablo 5). 12 aylık serilerde ise istatistiksel olarak anlamlı sonuçlara rastlanmadı. 36 aylık indis serilerinin analiz sonuçlarında, Karaman haricinde tüm istasyonlarda anlamlılık \%99 düzeyindedir. Çumra, Kulu, Karaman ve Cihanbeyli 24 aylık indislerinde \%99, Konya, Aksaray, Seydişehir, Niğde ve Ereğli ise $\% 95$ düzeyinde anlamlı sonuçlar verdi. Buna göre uzun süreli kuraklıklarda israr olduğu ve kurak-nemli dönemlerin birbirini izlediği, istatistiksel olarak ortaya konuldu.

Şekil 3'te 24 ve 36 aylık serilerin SPI değerlerindeki zamansal değişkenliği göstermek üzere grafikler verildi. İstasyonlarda kurak şartlardaki dönemsellik belirgindir. 19731974'deki kuraklık tüm istasyonlarda öne çıkar. Bu dönemin dışında da ortak kurak dönemler vardır. Konya istasyonunda öne çıkan, orta ve şiddetli kurak sınıfında yer alan dönemler 1988-1994 ile 1998-2008'dir (Şekil 3a). Aksaray'a bakıldığında 1997'e kadar daha kısa süreli ve hafif kurak dönemler belirginken, 1998-2008'de Konya ile benzer şekilde uzun bir kurak dönem dikkati çeker ve kuraklığın şiddetinin arttığı da gözlenebilir (Şekil 3b). Karaman istasyonunda 1982-2013 arası, aralarda birer yıllık nemli dönemlerde kesintiye uğrayan ve son yıllarda şiddeti hafiften orta kurak sınıfına geçiş gösteren bir kuraklık gidişi söz konudur (Şekil 3c). Kulu’da 2000li 
Tablo 5: Gidişler sınaması sonuçları.

Table 5: Results of Run's Test.

\%95 düzeyinde anlamlı \%95 düzeyinde anlamlı

\begin{tabular}{|c|c|c|c|c|c|c|c|}
\hline İstasyon & Test istatistikleri & KIS & 6 aylık & Yillık & 12 avlık & 24 avlık & 36 aylık \\
\hline \multirow{3}{*}{ Konya } & Gidiș sayı1s1 & 19 & 28 & 26 & 26 & 16 & 8 \\
\hline & Z Değeri & -1.4723 & 0.8884 & 0.2982 & .298 & -2.358 & -4.718 \\
\hline & Anlamlilik & 0.1409 & 0.3743 & 0.7655 & .766 & .018 & .000 \\
\hline \multirow{3}{*}{ Cihanbeyli } & Gidiș sayıs1 & 26 & 25 & 27 & 27 & 15 & 11 \\
\hline & Z Değeri & 0.2982 & 0.0031 & 0.5933 & .593 & -2.653 & -3.833 \\
\hline & Anlamllik & 0.7655 & 0.9975 & 0.5530 & .553 & .008 & .000 \\
\hline \multirow{3}{*}{ Aksaray } & Gidiș sayıs1 & 20 & 22 & 25 & 25 & 16 & 12 \\
\hline & Z Değeri & -1.1772 & -0.5870 & 0.0031 & .003 & -2.358 & -3.538 \\
\hline & Anlamlilik & 0.2391 & 0.5572 & 0.9975 & .997 & .018 & .000 \\
\hline \multirow{3}{*}{ Beyş ehir } & Gidiș sayıs1 & 20 & 24 & 24 & 24 & 18 & 14 \\
\hline & Z Değeri & -1.1772 & 0.0000 & 0.0000 & .000 & -1.767 & -2.948 \\
\hline & Anlamlilik & 0.2391 & 1.0000 & 1.0000 & 1.000 & .077 & .003 \\
\hline \multirow{3}{*}{ Karaman } & Gidiș sayıs1 & 24 & 24 & 24 & 24 & 12 & 16 \\
\hline & Z Değeri & 0.0000 & 0.0000 & 0.0000 & .000 & -3.538 & -2.358 \\
\hline & Anlamlilik & 1.0000 & 1.0000 & 1.0000 & 1.000 & .000 & .018 \\
\hline \multirow{3}{*}{ Ereğli } & Gidiș sayıs1 & 20 & 26 & 20 & 20 & 16 & 11 \\
\hline & Z Değeri & -1.0438 & 0.4473 & -1.0438 & -1.044 & -2.237 & -3.728 \\
\hline & Anlamllik & 0.2966 & 0.6546 & 0.2966 & .297 & .025 & .000 \\
\hline \multirow{3}{*}{ Niğde } & Gidiș sayıs1 & 20 & 24 & 22 & 24 & 16 & 12 \\
\hline & Z Değeri & -1.0438 & 0.0000 & -0.4473 & .000 & -2.237 & -3.429 \\
\hline & Anlamlilik & 0.2966 & 1.0000 & 0.6546 & 1.000 & .025 & .001 \\
\hline \multirow{3}{*}{ Kulu } & Gidiș sayıs1 & 18 & 26 & 25 & 25 & 14 & 15 \\
\hline & Z Değeri & -1.6402 & 0.4473 & 0.1491 & .149 & -2.833 & -2.535 \\
\hline & Anlamllik & 0.1010 & 0.6546 & 0.8815 & .881 & .005 & .011 \\
\hline \multirow{3}{*}{ Seydiş ehir } & Gidiș sayıs1 & 22 & 24 & 23 & 23 & 17 & 14 \\
\hline & Z Değeri & -0.4473 & 0.0000 & -0.1491 & -.149 & -2.062 & -2.948 \\
\hline & Anlamllik & 0.6546 & 1.0000 & 0.8815 & .881 & .039 & .003 \\
\hline \multirow{3}{*}{ Çumra } & Gidiș sayıs1 & 20 & 20 & 20 & 20 & 14 & 16 \\
\hline & Z Değeri & -1.0438 & -1.0438 & -1.0438 & -1.044 & -2.948 & -2.358 \\
\hline & Anlamlilik & 0.2966 & 0.2966 & 0.2966 & .297 & .003 & .018 \\
\hline \multirow{3}{*}{ Karapinar } & Gidiş sayıs1 & 20 & 24 & 24 & 24 & 18 & 14 \\
\hline & Z Değeri & -1.0438 & 0.0000 & 0.0000 & .000 & -1.640 & -2.948 \\
\hline & Anlamlilik & 0.2966 & 1.0000 & 1.0000 & 1.000 & .101 & .003 \\
\hline
\end{tabular}

yılların başına kadar kısa süreli kurak dönemler (1973-1974, 1983-1987) gözlenirken, 2001 itibariyle 2019'a kadar uzun, ağırlıklı hafif ve orta ancak bazı yıllar şiddetli kurak özelliği gösteren bir kurak dönem dikkati çeker (Şekil 3d). Ereğli'de 1982-2007 yılları arasında uzun ve bazı yıllar ekstrem kuraklıkların gerçekleştiği bir dönem gözlenirken (Şekil 3e); Beyşehir ile birlikte havzanın en yağışlı istasyonu olan Seydişehir'de ise 1982-1994 yılları arasındaki kuraklık dikkat çekicidir. Seydişehir istasyonunda ayrıca 1973-1976 yıllarında ekstrem kuraklık, 2000'li y1llarda ise hafifi-orta kuraklıklar dikkati çeker (Şekil 3f).

Şekil 4 ve Şekil 5'te seçilmiş iki yıl olan 1974 ve 2001 üzerinden $6,12,24$ ve 36 ylllık sürelerde, istasyonlar için hesaplanmış SPI değerlerinin havzadaki dağılışını gösteren haritalar verildi. 1974 y1lı havza genelinde kurak bir y1l olarak dikkati çeker. 1974 yılı verisi 24 aylık için 1974 ve 1975 yılı yağış toplamını, 36 aylık için ise 1974-1976 yılı yağış toplamını ifade eder. 6 Aylık serilerde Cihanbeyli ve Çumra'da hafif kuraklık ve Ereğli'de orta kuraklık durumu, havzanın geri kalanında ise şiddetli kuraklık görülür. 12 aylık SPI haritasında Cihanbeyli'de Hafif kuraklık görülürken, havzanın doğu ve batısında şiddetli-aşırı kuraklık (Niğde çevresi) ve orta bölümünde ise orta kuraklık hâkim olmuştur. 24 ve 36 aylık serilerde aşırı kuraklığın alanının genişlediği, batıda Beyşehir Gölü çevresinde Niğde'de yoğunlaştı̆̆ gözlendi. 36 aylık dönemde aynı zamanda Kulu da aşırı kuraklık özelliği göstermiştir. Bu iki dönemde hafif kuraklık gözlenmezken, iç bölgelerde orta ve şiddetli kuraklıklar hakimdir (Şekil 4).

Şekil 5'te sunulan 2001 yılı kuraklık haritalarında ise, farklı bir kuraklık deseni gözlendi. 1974'ün tersi bir biçimde 12, 34, 36 aylık gibi uzun dönemlerde değil de 6 aylık kuraklık haritasında şiddetli ve aşırı kuraklık durumu vardır. Burada, Aksaray aşırı kurak, havzanın güney ve doğusu ise şiddetli kurak karakterdedir. Kuzeyde Cihanbeyli'de kuraklık gözlenmezken, havzanın geri kalanında ise hafif ve orta kuraklık egemendir. 12 aylık SPI haritasında bu kez kuraklık paterni kuzeyde Tuz Gölü çevresinde 


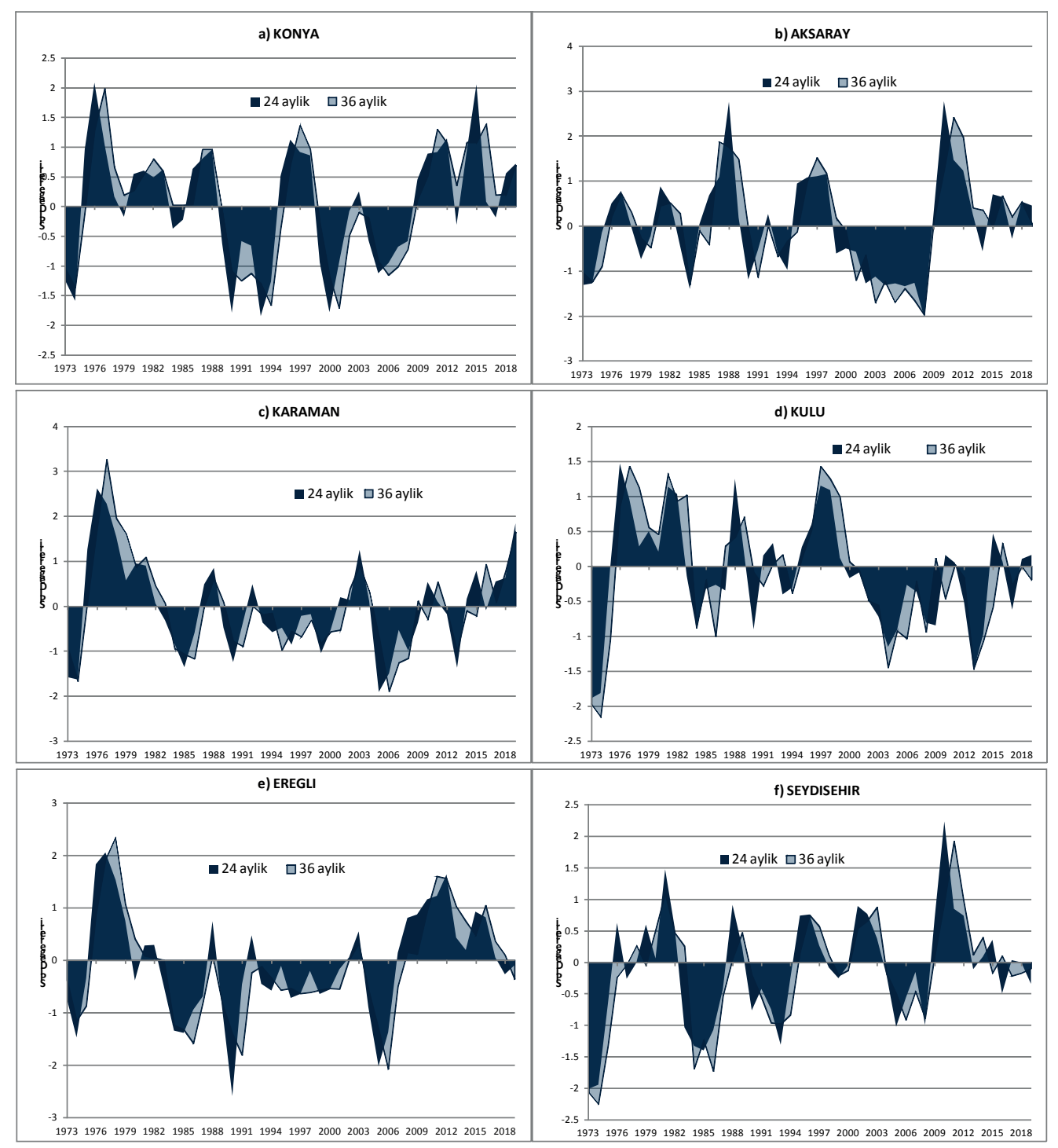

Şekil 3: Seçilmiş istasyonlarda SPI değerlerinin yılla- arası değişkenliği.

Figure 3: Inter-annual variability of SPI values at selected stations.

orta ve şiddetli kurak iken güneyde ağırlıklı olarak hafif kuraklık özelliği gösterir. 24 ve 36 yıllık SPI haritalarında baskın olan kuraklık türü hafif kuraklık olup, Konya, Cihanbeyli ve Aksaray'da orta kuraklık tespit edildi (Şekil 5).

\section{SONUÇ VE ÖNERILLER}

Konya Kapalı Havzası için 91-47 yıl arası uzunlukta yağış verisi olan 11 meteoroloji istasyonu ile gerçekleştirilen kuraklık analizi sonucunda elde edilen başlıca bulgular aşağıdaki gibi özetlenebilir:

1. Kısa süreli yağı̧s serilerinde, orta ve şiddetli kuraklıklar daha fazla gözlendi. Aylık bazda Aralık ayı dışında aşırı kuraklık tespit edilmedi. Şiddetli ve aşırı kuraklık tespit edilen dönemler ağırlıklı olarak Aralık, kış ve 6 aylık dönem oldu.

2. Kısa süreli yağış serilerinde, aşırı kuraklık sınıfında en yüksek yıl oranlarına Aralık ayında Ereğli (\%13.3) ve Karaman'da (\% 10) ulaşı1ld. Şiddetli kuraklık sınıfına giren yıl oranı bakımından Aksaray, Konya, Çumra ve Ereğli öne çıkan istasyonlardır. Orta kuraklık karakterindeki yıl sayısı geçiş mevsimlerinde veya bu mevsimler içerisindeki aylarda daha yüksek oldu.

3. Uzun süreli (12, 24 ve 36 aylık) yağış serilerinde özellikle şiddetli ve aşırı kurak yılların oranı kısa süreli serilerden belirgin biçimde yüksektir. Uzun süreli serilerdeki bu durum aynı zamanda tarımsal ve hidrolojik kuraklığın geliştiğine dair bir gösterge oluşturmaktadır. Uzun süreli yă̆ı̧̧ serilerinde daha şiddetli kuraklıklar gözlendi. 


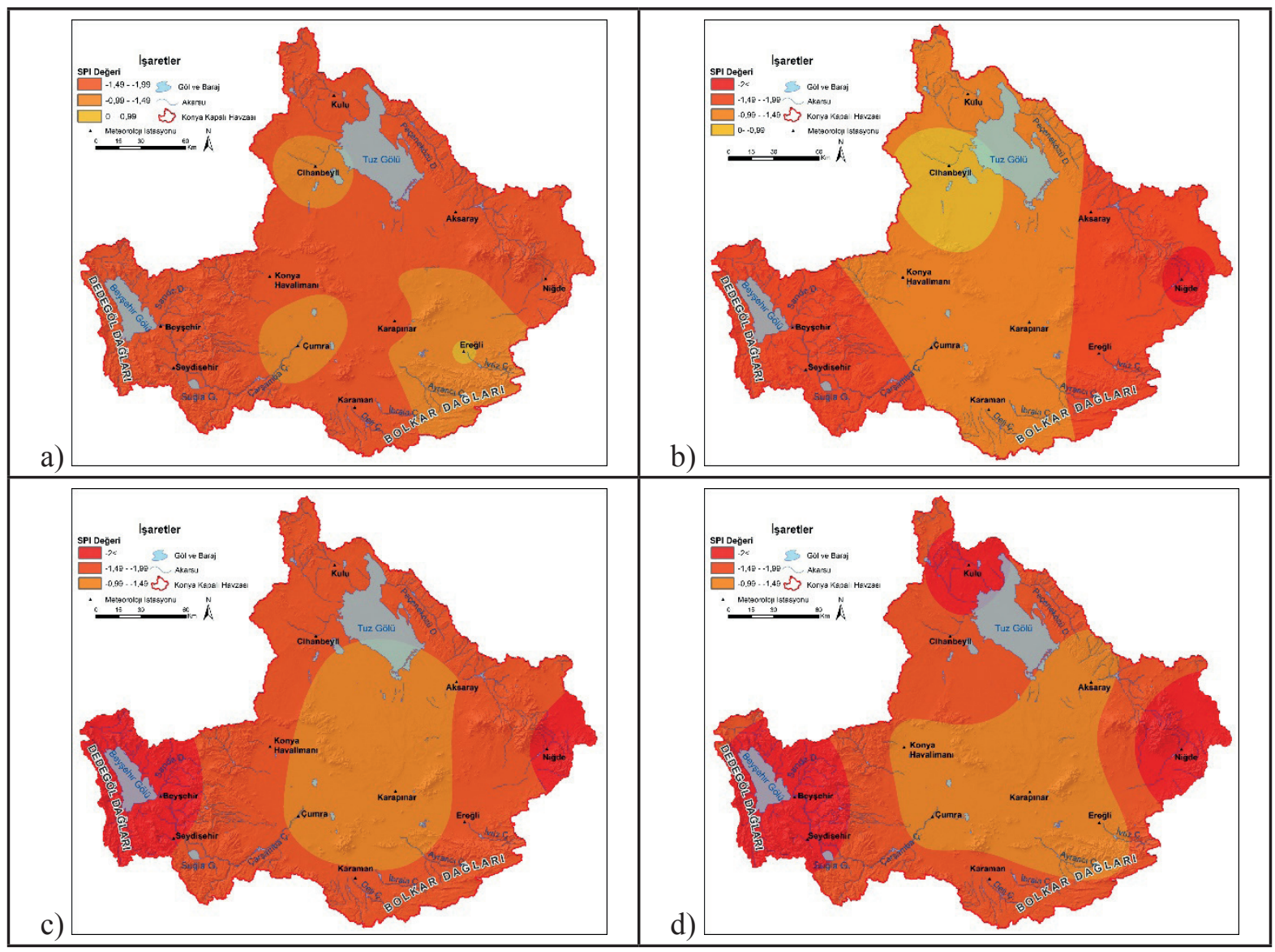

Şekil 4: 1974 yılı indis değerlerinin alansal dağılımı (a) 6 aylık, (b) 12 aylık, (c) 24 aylık ve (d) 36 aylık. Figure 4: Spatial distribution of 1974 index values (a) 6-month, (b) 12-month, (c) 24-month and (d) 36-month.

Cihanbeyli, Aksaray ve Beyşehir istasyonlarında şiddetli kuraklıkların oranı daha yüksekken, aşırı kuraklıklar açısından ise Beyşehir, Ereğli, Niğde ve Seydişehir öne çıkar.

4. Şiddetli kuraklık kategorisinde tanımlanan yılların oranı, 12 aylık analizlerde Aksaray'da (\%18.5), 24 aylık analizlerde \%12.5 ile Konya'da ve 36 aylık serilerin indis sonuçlarına göre ise Aksaray ve Beyşehir istasyonlarında (\%14.3) en yüksek yıl oranına sahiptir.

5. Uzun süreli serilerde Cihanbeyli, Karaman, Çumra ve Karapınar'da aşırı kurak yıl saptanmadı. Niğde 12 aylık ve 24 aylık analizler sonucunda en yüksek aşırı kurak yıl oranına (\%7.3) sahip istasyondur. 36 aylık SPI sonuçlarına göre ise havzada en yüksek aşırı kurak değerlerine sahip olan istasyon Beyşehir'dir (\%7.1).

6. SPI değerlerine uygulanan Gidişler sınaması sonuçlarına göre, 36 aylık kuraklık dönemi serilerinde tüm istasyonlar, 24 aylık serilerde ise Beyşehir ve Karapınar hariç bütün istasyonlar istatistiksel olarak anlamlı sonuçlara sahiptir. $\mathrm{Bu}$ sonuç bu kuraklık serilerindeki dönemselliği vurgular.
7. Şiddetli ve aşırı kurak yıllar 1973-1974, 1982-1984, 1988-1990 ve 2000-2002 ve 2012-2014 olarak gözlendi. Havza geneli için yaklaşık olarak 10 yılda bir gerçekleşen kurak dönemlerden söz edilebilir.

Çalışma sonucunda elde edilen ve yukarıda özetlenen bulguların önceki çalışmalarla bazı benzerlikleri söz konusudur. Türkeş vd.'nin (2009) Palmer Kuraklık İndisi ile yaptıkları çalışmada Konya, Karaman, Karapınar ve Aksaray istasyonlarının kurak dönemleri 1970'li ve 2000'li yılların baş1 olarak belirtilmiştir; aynı bulgu, bu çalışmada da elde edildi. Orhan ve Ekercin (2015) 1984-2011 yılları arasında Konya Kapalı havzasında sıcaklık artışı ve toprak nemindeki azalmaya bağlı olarak kuraklığın şiddetlendiği ifade etmiştir. Bu çalışmada uzun süreli dönemlerde gözlenen şiddetli ve aşırı kurak yıllar özellikle Konya, Ereğli, Aksaray ve Karaman'da benzer dönemde yoğunlaşır. Yağı̧ açı̆̆ı süresinin uzaması zaten kuraklığın meteorolojik karakterden, toprak nem açığı ile birlikte tarımsal ve ardından hidrolojik kuraklığa doğru ilerlemesine neden olur. Bunlara ek olarak Doğan (2013) ve Meriç, (2017) tarafından 


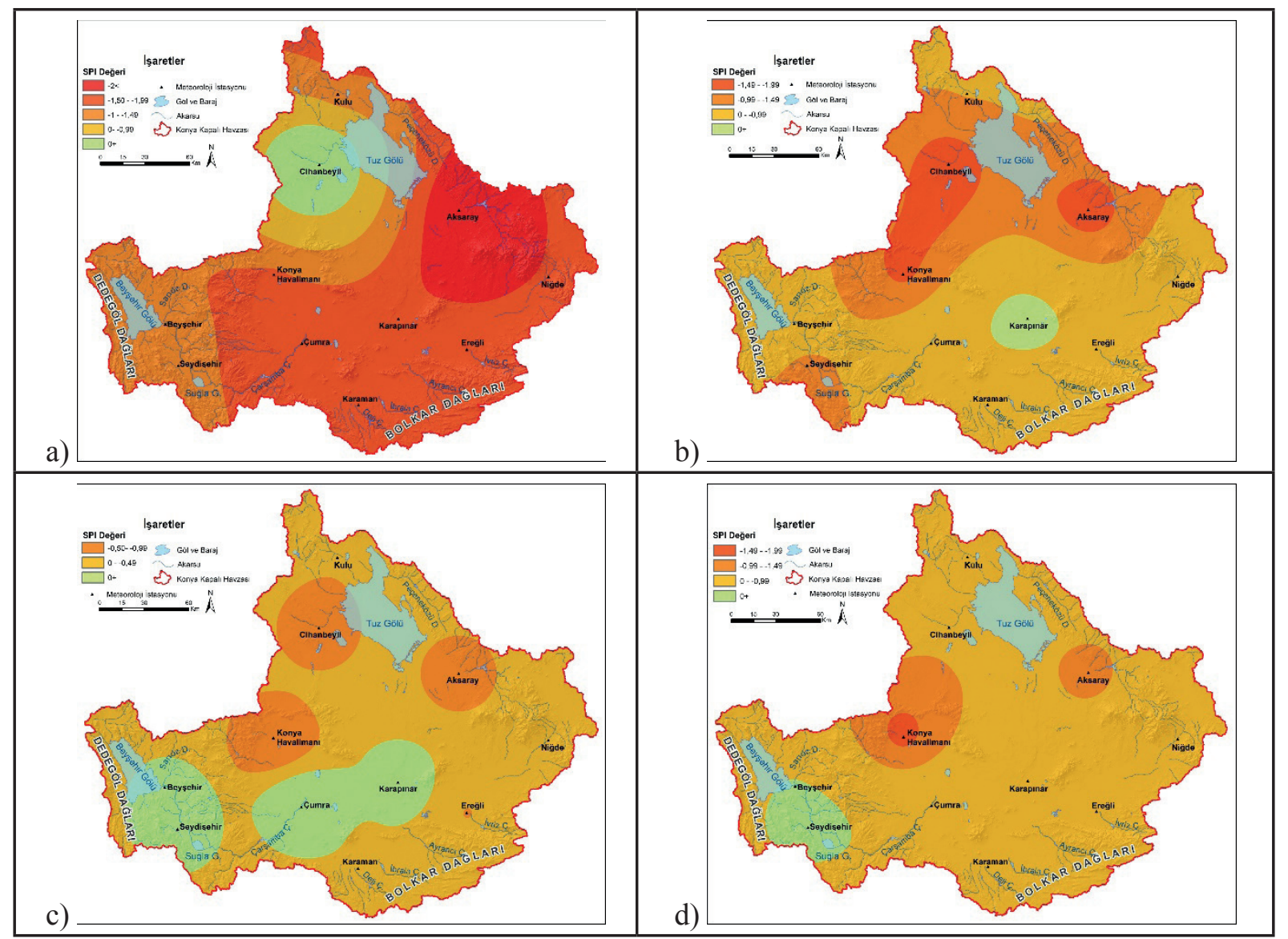

Şekil 5: 2001 yılı indis değerlerinin alansal dağılımı (a) 6 aylık, (b) 12 aylık, (c) 24 aylık ve (d) 36 aylık.

Figure 5: Spatial distribution of 1974 index values (a) 6-month, (b) 12-month, (c) 24-month and (d) 36-month.

yapılan çalışmalarla da havzadaki kurak yılların oransal dağılımı açısından benzerlikler söz konusudur. Bu çalışmada, 20 farklı zamansal ölçekte uygulanan SPI analizleriyle, Konya Kapalı havzasında kuraklığın zamansal değişkenlik paterni ve hidrolojik döngü çerçevesinde farklı rezervuarlarda yayılışı istatistiksel olarak ortaya konmuş oldu.

Kuraklık hidro-meteorolojik kökenli afetler arasında yavaş gelişen ancak etkileri uzun sürebilen bir afet olarak dikkati çeker. Birleşmiş Milletler Dünya Su Değerlendirme Programı 2019 raporuna göre küresel ölçekte neden olduğu kayıplar açısından yıllık ortalama değerlere bakıldığında; kuraklıktan etkilenen insan sayıs1 55 milyon, hayatını kaybeden insan sayısı 1100 ve neden olduğu ekonomik zarar ise 5.4 milyar ABD Doları'dır (UN-WWDP, 2019). İklim değişikliğinin en önemli etkileri su kaynakları üzerinde yaşanmaktadır. Bu nedenle, kuraklığın analizi, izlenmesi ve etkilerinin azaltılması yönünde bilimsel çalı̧̧malar artmakta ve özellikle havza yönetimi yaklaşımı çerçevesinde kuraklık yönetimi ön plana çıkmaktadır. Türkiye'de 2004 yılı itibariyle Havza Koruma Eylem Planları hazırlanması çalışmaları başlamış, 2010 yılında tamamlanmış ve 2014 yılından bu yana da bazı havzalarda uygulama aşamasına geçilmiştir (Tarım ve Orman Bakanlığı Web Sitesi, 2021). Konya Kapalı Havzası için Tarım ve Orman Bakanlığı bünyesinde gerçekleştirilen çalışmalarda havzadaki en önemli baskı unsurlarından birinin de yağış ve su azlığı olduğu vurgulanmakta ve özellikle en önemli ve büyük tatlı su kaynağı olan Beyşehir Gölü’ndeki seviye azalmasına dikkat çekilmektedir. Yağı̧̧ azlığının yanı sıra, buharlaşmanın yüksekliği, aşırı su çekimi ve tarımsal amaçlı su tüketiminin halen çok yüksek olması kuraklığın etkisini/şiddetini artıran faktörlerdir. Bu nedenle, bilimsel çalışmalarla açıkça ortaya konan su azlığı durumu göz önünde bulundurularak, tarımsal sulama başta olmak üzere su tüketiminin sınırlandırılması ve atık suların farklı sektörlerde yeniden kullanımı gibi su verimini artıracak uygulamalara geçilmeli ve tüm su kullanıcıları ortak sürdürülebilirlik hedefleri çerçevesinde hareket etmelidir. Ancak, Türkiye'de havza bazlı çalışmaların entegre bir şekilde yürütülmesinde paydaşlar arasındaki koordinasyon eksikliğinden kaynaklı idari bazı sorunlar söz konusudur. Bu anlamda kamu kurumları, üniversite, 
özel sektör ve sivil toplum ortak hareket ederek ve öncelikli olarak doğal kaynakların korunması ve sürdürülebilirliği ön plana alarak başarılı havza koruma eylem planları üretilebilir ve yalnızca kuraklık değil, havzalardaki pek çok soruna çözüm bulunabilir.

Teşekkür: Verilerin temin edilmesindeki yardımlarından dolayı MGM Meteorolojik Veri İşlem Dairesi Başkanlığı'na teşekkür ederiz.

Acknowledgement: We would like to thank MGM Meteorological Data Processing Department for their assistance in obtaining the data.

Hakem Değerlendirmesi: Dış bağımsız.

Çıkar Çatışması: Yazarlar çıkar çatışması bildirmemiștir.

Finansal Destek: Çanakkale Onsekiz Mart Üniversitesi Bilimsel Araştırma Projeleri (BAP) Komisyonu tarafından SYL-2020-3399 proje kodu ile desteklenmektedir.

Peer-review: Externally peer-reviewed.

Conflict of Interest: The authors have no conflict of interest to declare.

Grant Support: It is supported by the Scientific Research Projects (BAP) Commission of Çanakkale Onsekiz Mart University with the project code SYL-2020-3399.

\section{KAYNAKÇA/REFERENCES}

Akın, B. (2019). Tuz Gölü Havzası'nın kuraklık analizi. (Yüksek Lisans Tezi). Sakarya Üniversitesi Sosyal Bilimler Enstitüsü, Sakarya.

Akın, G. (2006). Küresel 1sınma, nedenleri ve sonuçları. Ankara Üniversitesi Dil ve Tarih-Coğrafya Fakültesi Dergisi, 46(2), 29-43.

Ceylan, A., Akgündüz, S., Dermirörs, Z., Erkan, A., Çınar, S. ve Özveren, E. (2009, Haziran). Aridity index kullanarak Türkiye'de çölleşmeye eğilimli alanlardaki değişimin belirlenmesi. I. Ulusal Kuraklık ve Çölleşme Sempozyumu, Konya.

Çiçek, İ. ve Y1lmaz, E. (2016). Türkiye Thornthwaite iklim sınıflandırması. Beşerî Bilimler Dergisi, 13(3), 3973-3994.

Çiftçi, Ç., Dursun, Ş., Levend, S. ve Kunt, F. (2013). Topografik yapı, iklim şartları ve kentleşmenin Konya'da hava kirliliğine etkisi. Avrupa Bilim ve Teknoloji Dergisi, 1(1), 19-24.

Doğan, S. (2013). Konya Kapalı Havzası'nda kuraklık karakterizasyonunun zamansal-konumsal analizi (Yüksek Lisans Tezi). Selçuk Üniversitesi Fen Bilimleri Enstitüsü, Konya.

Keskiner, A. D., Çetin, M., Uçan, M. ve Şimşek, M. (2016). Coğrafi bilgi sistemleri ortamında yağış indeksi yöntemiyle olasılıklı meteorolojik kuraklık analizi. Çukurova Tarım Gıda Bilim Dergisi, 31(2), 79-90.

Kılıç, N. (2016). Konya ili uzun yıllar yağış-sıcaklık kayıtlarının analizi. (Yüksek Lisans Tezi). Selçuk Üniversitesi Fen Bilimleri Enstitüsü, Konya.

Kol, Ç. ve Küpçü, S. (2008). ArcGIS 3D: Analiz ArcView, ArcEditor ve ArcInfo için. Ankara: Sinan Ofset Matbaacılık San. Tic. Ltd. Şti.

Mckee, T. B., Doesken, N. J. \& Kleist, J. (1993, January). The relationship of drought frequency and duration to time scales. Eighth conference on applied climatology, California. https://www. scinapse.io/papers/2153179024
Mendenhall, W. \& Reinmuth, J. (1982). Statistics for management and ecomonics (4th Ed)., Duxbury Press.

Mengü Pamuk G., Anaç S. ve Özçakal E. (2011). Kuraklık yönetim stratejileri, Ege Üniversitesi Ziraat Fakültesi Dergisi, 48(2): 175-181.

Meriç, Y. (2017). Konya Kapalı Havzası'nda TMPA uydu kaynaklı yağış verileri ile kuraklık analizi. Gazi Üniversitesi Mühendislik ve Mimarlık Fakültesi Dergisi, 32(2), 541-549.

Orhan, O. ve Ekercin, S. (2015, Mayıs). Konya Kapalı Havzası'nda uzaktan algilama ve CBS teknolojileri ile iklim değişikliği ve kuraklık analizi. 8. TUFUAB Teknik Sempozyumu, Konya.

Öztürk, M. Z., Çetinkaya, G. ve Aydın, S. (2017). Köppen-Geiger iklim sınıflandırmasına göre Türkiye'nin iklim tipleri. Coğrafya Dergisi, $35,17-37$.

Sarı, S. ve İnan, N. (2011). Seydişehir ve Beyşehir'in iklimlerinin karşılaştırılması. Selçuk Üniversitesi Sosyal Bilimler Enstitüsü Dergisi, 26, 291-310.

Sarış F. (2016). Porsuk Çayı Havzasında Düşük Akım Analizi. İstanbul Coğrafya Dergisi, 33, 73-81.

Sırdaş, S. ve Şen, Z. (2003). Meteorolojik kurakl1k modellemesi ve Türkiye uygulaması. ITÜ Dergisi, 2(2), 95-103.

Spinoni, J. Naumann, G., Carrao, H., Barbarosa, P. \& Vogt, J. (2013). World drought frequency, duration and severity for 1951-2010. International Journal of Climatology, 34, 2792-2804. https://doi. org $10.1002 \% 2$ Fjoc. 3875

Tekkanat, İ. S., \& Sarış, F. (2015). Porsuk Çayı Havzasında akarsu akımlarında gözlenen uzun dönemli eğilimler. Türk Coğrafya Dergisi, 64, 69-83.

TÜBİTAK Marmara Araştırma Merkezi Çevre Enstitüsü. (2010). Havza koruma eylem planlarının hazırlanması - Konya Kapalı Havzası. https:/www.tarimorman.gov.tr/ SYGM/Belgeler/havza\%20 koruma $\% 20$ eylem $\% 20$ planlar $\%$ C4\%B1/Konya_Kapali_Havzasi.pdf

Türkeş, M., Koç, T. ve Sarış, F. (2007). Türkiye'nin yağış toplamı ve yoğunluğu dizilerindeki değişkenlerin ve eğilimlerin zamansal ve alansal çözümlenmesi. Coğrafi Bilimler Dergisi, 5(1), 57-73.

Türkeş, M., Akgündüz, S. ve Demirörs, Z. (2009). Palmer Kuraklık İndisi'ne göre İç Anadolu Bölgesi’nin Konya Bölümü'ndeki kurak dönemler ve kuraklık şiddeti. Coğrafi Bilimler Dergisi, 7(2), 129-144.

Türkeş, M. (2012). Türkiye'de gözlenen ve öngörülen iklim değişikliği, kuraklık ve çölleşme. Ankara Üniversitesi Çevre Bilimleri Dergisi, 4(2), 1-32.

UN World Water Development Programme Annual Report (2019). Leaving no one behind. https://www.unwater.org/publications/ world-water-development-report-2019/

Van Loon, A. F. (2015). Hydrological drought explained. WIREs Water, 2 , 359-392. https://onlinelibrary.wiley.com/doi/abs/10.1002/wat2.1085

Yılmaz, M. (2010). Karapınar çevresinde yeraltı suyu seviye değişimlerinin yaratmış olduğu çevre sorunları. Ankara Üniversitesi Çevre Bilimleri Dergisi, 2(2), 145-163.

Yaprak, S. ve Arslan, E. (2008). Kriging Yöntemi ve Geoit Yüksekliklerinin Enterpolasyonu. Jeodezi, Jeoinformasyon ve Arazi Yönetimi Dergisi, 98, 36-42. 